IZA DP No. 8431

The Changing Benefits of Early Work Experience

Charles L. Baum

Christopher J. Ruhm

August 2014

Forschungsinstitut zur Zukunft der Arbeit Institute for the Study of Labor 


\title{
The Changing Benefits of Early Work Experience
}

\author{
Charles L. Baum \\ Middle Tennessee State University \\ Christopher J. Ruhm \\ University of Virginia, \\ NBER and IZA
}

Discussion Paper No. 8431

August 2014

\author{
IZA \\ P.O. Box 7240 \\ 53072 Bonn \\ Germany \\ Phone: +49-228-3894-0 \\ Fax: +49-228-3894-180 \\ E-mail: iza@iza.org
}

\begin{abstract}
Any opinions expressed here are those of the author(s) and not those of IZA. Research published in this series may include views on policy, but the institute itself takes no institutional policy positions. The IZA research network is committed to the IZA Guiding Principles of Research Integrity.

The Institute for the Study of Labor (IZA) in Bonn is a local and virtual international research center and a place of communication between science, politics and business. IZA is an independent nonprofit organization supported by Deutsche Post Foundation. The center is associated with the University of Bonn and offers a stimulating research environment through its international network, workshops and conferences, data service, project support, research visits and doctoral program. IZA engages in (i) original and internationally competitive research in all fields of labor economics, (ii) development of policy concepts, and (iii) dissemination of research results and concepts to the interested public.
\end{abstract}

IZA Discussion Papers often represent preliminary work and are circulated to encourage discussion. Citation of such a paper should account for its provisional character. A revised version may be available directly from the author. 
IZA Discussion Paper No. 8431

August 2014

\section{ABSTRACT}

\section{The Changing Benefits of Early Work Experience*}

We examine whether the benefits of high school work experience have changed over the last 20 years by comparing effects for the 1979 and 1997 cohorts of the National Longitudinal Survey of Youth. Our main specifications suggest that the future wage benefits of working 20 hours per week in the senior year of high school have fallen from 8.3 percent for the earlier cohort, measured in 1987-1989, to 4.4 percent for the later one, in 2008-2010. Moreover, the gains of work are largely restricted to women and have diminished over time for them. We are able to explain about five-eighths of the differential between cohorts, with most of this being attributed to the way that high school employment is related to subsequent adult work experience and occupational attainment.

JEL Classification: $\quad \mathrm{J} 13, \mathrm{~J} 24, \mathrm{~J} 31$

Keywords: $\quad$ youth employment, work experience, wages

Corresponding author:

Christopher J. Ruhm

University of Virginia

204 Garrett Hall, 235 McCormick Rd.

P.O. Box 400893

Charlottesville, VA 22904-4893

USA

E-mail: ruhm@virginia.edu 


\section{Introduction and Background}

Early work experience in high school, by facilitating the transition from school to the labor force, is believed by some to be important for later economic success (Bailey, 1995; Bishop, 1996; Osterman, 1995; Poczik, 1995). Students who are employed in high school may enhance their future employment prospects and earnings potential by learning work-related skills and forging contacts with employers. In addition, the impact of early work experience on earnings may have increased as the return to skill has risen (Oettinger, 1999). However, others (Greenberger and Steinberg, 1986; Staff, Schulenberg, and Bachman, 2010; Monahan, Lee, and Steinberg, 2011) believe that intensive early work experience is detrimental to later economic success, in part, because it harms academic performance (like high school graduation and college attendance rates). Understanding the effects of early work experience is important in its own right, and even more so because the prevalence of high school employment decreased rapidly during the first decade of the $21^{\text {st }}$ century. For example, analysis of Current Population Survey data by the National Center for Education Statistics (2012) reveals that the employment rate of high school students (aged 16 and older) remained roughly constant (at around 32 percent) during the 1990s, but decreased rapidly after 2000, such that only 16 percent were employed in $2010 .{ }^{1}$

${ }^{1}$ Possible reasons for the decline include the Great Recession (December 2007 through June 2009), increased competition for jobs from immigrants, former welfare recipients and other adults, as well as an increased emphasis on education and in the availability of financial aid for college (Aaronson, Park, and Sullivan, 2006; Astone, Hao, and Cherlin, 2004; Gottschalk and Hansen, 2003; Sum, Harrington, and Khatiwada, 2006; Smith, 2011; 2012). Since our later cohort were high school students around the turn of 
We address these issues by using data from two cohorts of the National Longitudinal Survey of Youth (NLSY) to study how the employment of high school students, particularly seniors, is related to subsequent labor market outcomes. Most previous research uses data for the 1979 cohort of the NLSY (NLSY79). We supplement this with data from the 1997 cohort (NLSY97), which includes youths who were in high school around the turn of the millennium. In addition to examining how the associations between student employment and future labor market outcomes have shifted over time, we attempt to identify the reasons for the changes. Our main finding is that working during the senior year of high school yields significantly smaller future labor market benefits for the recent (NLSY97) cohort than for the earlier (NLSY79) one. For example, the average wage premium from 20 weekly hours of senior work experience is about twice as large for NLSY79 respondents in 1987-1989 (8.3 percent) as for their NLSY97 counterparts in 2008-2010 (4.4 percent). Our estimates suggest that one-half to two-thirds of this trend operates through effects on subsequent labor market experience and occupational attainment. Specifically, senior year employment was predicted to decrease the probability of subsequently working in the relatively lowpaid service sector for the 1979 cohort but to increase it for the 1997 cohort. In addition, working during high school has a smaller estimated positive effect on post-high school work experience for the later group than for the earlier one and the returns to this experience have also trended downwards. Conversely, changes in the effects of high school employment on educational attainment do not play much of a role.

the millennium, as discussed below, this reduction in high school employment is not directly observed in our analysis. 


\section{Theory and Existing Evidence}

The human capital, signaling, and occupational socialization models all suggest conditions under which adult wages will be enhanced by high school employment. For instance, using the human capital model (Becker, 1975; Mincer, 1974), high school work experience might improve future labor market outcomes because employed students acquire skills and knowledge that increase their productivity. This effect might be complemented in the screening model (Spence, 1973; Arrow, 1973) if market work in high school is a signal of high labor productivity. These effects will be reinforced if, as predicted by the occupational socialization model, working during high school promotes favorable work attitudes, stronger work orientation, higher self-reliance, better time management skills or positive self-concepts (Mortimer and Finch, 1986; Steel, 1991). ${ }^{2}$ Alternatively, high school employment might have negative effects. For instance, it could decrease cognitive skill accumulation by reducing educational attainment, as proxied by high school GPA, dropout or graduation rates, and college attendance (Greenberger and Steinberg, 1986), in part because it reduces the time available for studying (Kalenkoski and Pabilonia, 2009; 2012) or increases stress or exhaustion (Steinberg, Fegley, and Dornbusch, 1993).

Most previous research finds that high school employment enhances future employment opportunities and increases wages (Carr, Wright, and Brody, 1996; Hotz, Xu, Tienda, and Ahituv, 2002; Light, 1999, 2001; Marsh, 1991; Meyer and Wise, 1982; Mortimer and Finch, 1986; Ruhm, 1997; Steel,

${ }^{2}$ Stern and Nakata (1989) suggest that early work experience develops on-the-job "learning” skills, which help employees approach new problems effectively, understand the steps required to complete assignments, identify the information needed to complete an operation, or devise a means by which to attain requisite information. Stern and Nakata believe developing the ability to learn on the job is becoming more important with technological change, increased employee decision-making, and the economy's shift from high-volume manufacturing to low-volume specialized production. 
1991; Stephenson, 1981; Stern and Nakata, 1989). ${ }^{3}$ Ruhm (1997) shows that early work experience during the senior year has positive effects on future hourly and annual earnings, fringe benefits (e.g., retirement pensions and health insurance), and occupation status measured 6 to 9 years later. Meyer and Wise (1982) find that post-high school annual employment increases by 1.5 weeks and wages by 5 to 9 percent for every five additional hours of work per week during high school. Light (1999) indicates that high school employment raises wages for the first six years after graduation - by six percent for working 25 hours per week, versus not working - but with the effects disappearing by 7 or 8 years after graduation. Light (2001) suggests that two years of in-school employment raise the wages of college graduates by 10 to 18 percent. Carr, Wright, and Brody (1996) estimate that high school employment increases labor force participation, employment, and income measured ten years later. Conversely, Hotz, Xu, Tienda, and Ahituv (2002) conclude that the positive effects of high school work on wages found in the literature are due to unobserved heterogeneity. However, Light (2001) believes that this is because Hotz et al. (2002) examine whether or not students work rather than differences in work intensities.

${ }^{3}$ Stern, Finkelstein, Urquiola, and Cagampang (1997) differentiate between the effects of "co-op” versus “non-school-supervised” work, with co-op work defined as where teachers and employers develop a workrelated training plan for the student. They show that both types of employment significantly decrease high school grades, but the negative effects of non-school-supervised work are larger than those of co-op jobs. Neumark and Joyce (2001) use NLSY97 data to study the effects of school-to-work programs on current school enrollment, employment, hours of work, wages, and educational attainment and on expectations of future education and employment. They find similar effects of program participation on students' expectations but none on any of the other outcomes. Their results must be interpreted with caution because data are from the 1997 wave when respondents were roughly 12 to 16 years of age, when many of the outcomes were seldom observed. 
Other studies investigated effects on educational performance during high school. ${ }^{4}$ Early research (e.g. Greenberger and Steinberg, 1980; Marsh, 1991; Mortimer and Finch, 1986; Steinberg and Dornbusch, 1991; Steinberg, Greenberger, Garduque, and McAuliffe, 1982; Steinberg, Greenberger, Garduque, Ruggiero, and Vaux, 1982; and Steinberg, Fegley, and Dornbusch, 1993) shows that high school hours have detrimental effects on multiple measures of high school performance, particularly for students working intensively (more than 20 hours per week). Some later investigations concur (Carr, Wright, and Brody, 1996; Eckstein and Wolpin, 1999; Oettinger, 1999; Tyler, 2003), while others find that modest amounts of work may have positive consequences (D’Amico, 1984; DeSimone, 2006; Lillydahl, 1990; Mortimer, Finch, Ryu, Shanahan, and Call, 1996; Schill, McCartin, and Meyer, 1985; Steel, 1991) or no effect on academics (Buscha, Maurel, Page, and Speckesser, 2011; Gottfredson, 1985; Lee and Orazem, 2010; Montmarquette, Viennot-Briot, and Dagenais, 2007; Sabia, 2009), or that any “effects” are primarily due to unobserved characteristics such as preexisting preferences for work over school (Bachman, et al., 2003, 2008, 2011; Rothstein, 2007; Schoenhals, Tienda, and Schneider, 1998; Staff, Schulenberg, and Bachman, 2010; Warren, 2002; Warren and Lee, 2003; Warren, LePore, and Mare, 2000). ${ }^{5}$

${ }^{4}$ Yet another line of research examines the effects of summer youth employment programs on academic and behavioral outcomes (e.g., see LaLonde, 2003, and Leos-Urbel, 2012).

${ }^{5}$ Ehrenberg and Sherman (1987), Stinebrickner and Stinebrickner (2003) and Arano and Parker (2008) examine the consequences of employment while in college. Ehrenberg and Sherman find little impact on grades but that off-campus employment negatively affects enrollment and on-time graduation. Stinebrickner and Stinebrickner find college work decreases grades. Other related studies have examined the effects of high school students’ marketplace work on psychological factors. 


\section{Data}

Data are from the 1979 and 1997 National Longitudinal Survey of Youth cohorts (NLSY79 and NLSY97). The NLSY is well-suited for our purposes because it collects detailed information about the employment experiences and background and school characteristics of high school students, as well as their subsequent labor market outcomes many years later. From 1979 through 1994, the NLSY79 annually interviewed a cohort of respondents aged 14 - 21 in 1979. After the 1994 survey, the NLSY79 began interviewing biennially, and these respondents have since been reinterviewed on that basis. The original NLSY79 sample contained 12,686 individuals, including 6,283 females and oversamples of blacks, Hispanics, low-income whites, and military personnel. The military sample was dropped in 1984 and the low-income white sample in 1990. We exclude both from our analysis because the NLSY97 does not contain comparable oversamples. The NLSY97 began annually interviewing 8,984 youths, aged 12 through 16 on January 1, 1997, and is ongoing. The NLSY97 sample contains 6,748 cross-sectional observations and an oversample of 2,236 additional black and Hispanic respondents.

The NLSY79 cohort is used to examine how high school work experience occurring at the turn of the $21^{\text {st }}$ century is related to the subsequent labor market outcomes of adults, aged 26 to 30 , in 2010. The 1979 NLSY cohort provides corresponding information on the effects of high school employment occurring during the 1980s, or approximately 20 years earlier.

\section{$\underline{\text { High School Employment }}$}

The NLSY identifies labor force status in each week covered by the surveys. Respondents report being employed, unemployed, or out of the labor force and the number of hours worked in 
each week (if employed). ${ }^{6}$ Following Ruhm (1997), we use the months of October, November, February, March, April, and May for academic-year work experience to avoid employment during times out of school (e.g., Christmas break or summer break). Where possible, we identify early work experience during the sophomore, junior, and senior high school grades, although most of our analysis focuses on senior year employment because the effects are smaller or nonexistent at younger ages. Our primary specifications examine average weekly work hours during the academic year but we also present results for non-linear work hours effects and for average hours worked per week during the summer between the junior and senior years. ${ }^{7}$ We top-code work hours at 40 when respondents working longer hours during the academic year. ${ }^{8}$

${ }^{6}$ The NLSY97 identifies whether respondents (aged 14 and over) work at an “employee-type” job (for a regular employer) or a "freelance-type" job (where the youth has no boss or works for him or herself) in each week from 1994 through the most recent survey. The NLSY79 work history begins January 1, 1978 and does not distinguish between employee-type and freelance-type employment. For this reason, we make no such a distinction in our analysis, but we acknowledge this may mask heterogeneous effects on later economic outcomes, particularly for younger students if they are the ones most likely to babysit, cut grass, etc.

${ }^{7}$ Following Ruhm (1997), we use the eight-week period beginning July 1 to reflect summer employment experiences.

${ }^{8}$ An alternative to the work history data is to use status in the week prior to the survey. Ruhm (1997) prefers the accuracy of reference week measures and supplies evidence that hours worked in recall data are often overstated. However, Rothstein (2007) points out that recall data offers the "major" advantage of covering the entire academic (or summer) period, noting that because work hours tend to increase over the academic 
The youngest NLSY97 respondents (who were 12 years of age in 1997) were in high school from approximately 1999 through 2003 and the oldest (aged 17 in 1997) from about 1994 through 1998. Thus, high school work experience for the 1997-cohort NLSY occurred from approximately 1994 through 2003, but was only observed in the data starting in 1997. The youngest NLSY79 respondents (who were 14 in 1979) were in high school from approximately 1981 through 1985 and the oldest (aged 21 in 1979) from about 1972 through 1976. The NLSY79 work history begins with the first week of January 1978, so that high school work experiences for the 1979-cohort are available from 1978 through 1985. We examine labor market experiences at least five years after graduation, or from 2008-2010 for NLSY97 respondents (requiring high school graduation no later than 2003) and from 1987-1989 for NLSY79 respondents (requiring high school graduation no later than 1982).

We do not always have the information needed to identify early work experience during each year of high school. Most frequently, this is because the individual began high school before the start of the NLSY survey (e.g. for an NLSY79 respondent aged 16 in 1979). We include persons providing information identifying work experience during at least a portion of high school in most of the analysis, because it should be largely random whether a respondent's time in high school year, reference week work hours may be unduly influenced by the interview date. Work history data also allows academic year work hours and summer work to be compared. We use the recall data throughout the analysis because survey-week work hours are only collected in the 1997, 2000, and 2006 NLSY97 surveys. As did Ruhm (1997), we find that work hours in the NLSY work histories are approximately 10 to 15 percent higher than corresponding survey-week work hours. To explore how this influences the results, we re-estimated the preferred log wage models using reference week work hours. These yielded similar estimates that were less precise due to smaller samples. 
completely overlaps with the NLSY survey period (e.g., whether a NLSY79 respondent was 12 or 16 in 1979) and because we are reluctant to discard potentially useful information. However, we also conducted sensitivity analysis limiting the sample to those whose work experiences are identified in each high school year.

Table 1 presents descriptive statistics on high school work experience. Most high students (82 percent of NLSY79 respondents and 85 percent of the NLSY97 sample) are employed at some point during high school. Average work hours increase with high school grade from less than 5 per week for sophomores to 13 or 14 per week for seniors. Students work more during the summer between the junior and senior year than during either academic year. Three-quarters of students work at some point during their senior year; 30 percent for more than 20 hours per week and the overall prevalence of high school work changed relatively little over the analysis period. ${ }^{9}$

\section{$\underline{\text { Adult Labor Market Outcomes }}$}

Our primary dependent variable is the natural log of hourly wages measured when the respondents are 23-29 years old (or around 5-11 years after the expected date of high school graduation). We also analyze supplementary outcomes including: (i) whether the respondent is

${ }^{9}$ These statistics are similar to Ruhm's (1997) for the NLSY79 and Rothstein’s (2007) for the NLSY97, although both use slightly different sample selection criteria. For example, Ruhm reports that NLSY79 seniors work in 52.3 percent of the academic-year weeks compared to 55.9 percent in our sample (for NLSY79 respondents examined in the 1987-1989 period) and 12.3 hours per week compared to 13.3 hours in our sample. Rothstein shows that male (female) NLSY97 seniors work in 52.1 (57.0) percent of schoolyear weeks compared to 59.2 percent in our sample and in 12.9 (13.0) hours per week compared to 13.8 hours here. 
employed, (ii) annual weeks and hours worked, (iii) annual weeks unemployed, (iv) annual and weekly earnings, and (v) the receipt of medical insurance and retirement or pension benefits. All dollar figures are adjusted for inflation, using the CPI, to year-2012 dollars. The NLSY's weekly work history described above is used to create the measures of annual weeks and hours worked and annual weeks unemployed (and whether the adult was employed) on a calendar year basis. The NLSY surveys provide additional information on jobs held during the survey year-since the last interview — and this information is used to create the hourly wage and employment benefits measures on a survey year basis. Adult labor market outcomes are averaged across three survey waves or calendar years to smooth temporary fluctuations - the 2008-2010 surveys for NLSY97 respondents and the 1987-1989 surveys for NLSY79 respondents. When data is missing for one of these survey years, we average over the two remaining surveys to avoid losing observations.

Table 2 presents descriptive statistics on adult economic outcomes for the two cohorts. Hourly wages are slightly higher for the later (NLSY97) cohort, as expected since wages tend to grow over time, but the differences are small. Rates of employment and weeks worked are similar but weekly work hours appear to have fallen modestly over time, while unemployment has risen. The receipt of health insurance and retirement/pension plan benefits may have trended slightly downwards at the same time that education increased.

Table 3 shows the association between senior year high school employment and selected future labor market outcomes: hourly wages, annual weeks worked, and college degree completion, with the data weighted so as to provide nationally representative results. We divided senior grade workers into categories: $0,1-10,11-20$ and $>20$ hours, and did the same for employment during the summer prior to the senior year. Adult wages and weeks worked are typically lowest for those who did not work as students during the academic year and are generally highest for those who worked 
long hours. Interestingly, the gradient weakened over time, suggesting a lower return to student employment in recent years. College completion rates were highest for those who worked relatively short (0-10) hours in their senior year of high school. Summer employment positively correlates with future wages and weeks worked, but less so with educational attainment.

\section{Empirical Specification}

We use multivariate regression to explore the predicted effect of early work experience on adult labor market outcomes $\left(\mathrm{W}_{\mathrm{it}}\right)$, primarily log wages, which are measured for respondent $\mathrm{i}$ at time t. The key explanatory variables are early employment experiences $\left(E_{i t}\right)$. Formally, we estimate

$$
\mathrm{W}_{\mathrm{it}}=\beta_{0}+\boldsymbol{\beta}_{1} \mathbf{X}_{\mathrm{ist}}+\beta_{2} \mathrm{E}_{\mathrm{it}}+\varepsilon_{\mathrm{it}},
$$

where X, in the basic model, includes standard demographic controls for gender, race/ethnicity, age, marital status, family size, cigarette smoking, body mass index (BMI), region of residence, and urbanicity. Time-varying demographic characteristics (e.g., family size, region of residence) are measured during adulthood and included in all models and some specifications contain additional covariates. ${ }^{10}$ To prevent sample loss from missing values for covariates that are not the primary focus of our analysis, we generate a dummy variable for each regressor that equals one when the data are missing or incomplete, with that covariate then coded with a zero (e.g. see Tyler, 2003). We exclude from our basic model controls for adult occupation, education, work experience and tenure, since high school employment may affect adult labor market outcomes through these factors. Subsequent specifications include controls for these potential mediating factors.

High school employment is unlikely to occur randomly. Ideally, the supplementary covariates account for this non-random selection; however, the estimates may be biased if they do

${ }^{10}$ Descriptive statistics for selected demographic characteristics are supplied in Appendix Table A1. 
not. For example, if that high school students who work in the labor market have less academic ability, the estimated effect of early employment on later wages is likely to be biased downwards. Our primary strategy for minimizing this potential heterogeneity bias is to successively include more detailed controls for family background, student ability, and school characteristics that might reflect differences between high school students who are and are not employed. The characteristics available vary somewhat between the NLSY79 and NLSY97: the former contains more detailed family background information and the latter more information about school characteristics and experiences. Specifically, the vector of family background characteristics always includes mother's and father's education, living with both parents, whether English was spoken at home, town size, and religious affiliation. Church attendance is also included for NLSY97 respondents as are parents being foreign born and whether the household had magazine or newspaper subscriptions and the number of siblings for the NLSY79 sample. Ability is measured by the Armed Services Vocational Aptitude Battery (ASVAB) test score for the NLSY97 and the Armed Forces Qualifications Test (AFQT) score for the NLSY79. We also include eighth grade GPA as an ability measure for NLSY97 respondents. The covariate block of school characteristics and experiences for the NLSY97 includes the high school program (general, college preparatory, vocational, or combination); number of math and science courses taken; school type (public, private, or parochial) and size; and the school's student-teacher ratio. For the NLSY79, this includes program of study (vocational, commercial, college preparatory, or general); school type (public or private); and student perceptions of boredom, safety, and satisfaction with school. As an alternative method of dealing with nonrandom selection into high school employment, we used an instrumental variables (IV) strategy, where high school employment is predicted by local labor market conditions during 
the high school years (Ruhm, 1997; Light, 1999; Hoynes, 2000; Neumark, 2002). These methods and the results obtained using them are briefly discussed below. ${ }^{11}$

\section{The Benefits of Student Employment Have Declined Over Time}

We begin our empirical analysis by examining the effects of hours worked during the senior year on $\log$ hourly wages in adulthood (see table 4). We follow much of the previous literature by focusing on work by high school seniors and show below that this is where the predicted student employment effects are the strongest. Model 1 provides results for a specification that contains no covariates other than senior year work hours. Controls for demographic covariates, family background characteristics, ability, and school characteristics are successively added in models 2 through 5, with the last of these (which includes the full set of covariates) being focused upon in most of the subsequent analysis. Senior hours are calculated on a weekly basis and divided by 20 , so that a one unit change corresponds to working an additional 20 hours per week during the high school senior year.

For the 1979 cohort, senior work hours are positively and statistically correlated with future wages, with little change in the predicted effects occurring once the basic set of demographic characteristics (in

\footnotetext{
${ }^{11}$ We also estimated sibling-specific fixed effects models (Oettinger, 1999), which controlled for timeinvariant family characteristics but not factors differing between siblings or over time. The fixed effects results were mixed, suggesting student employment benefited subsequent labor market outcomes for the earlier but not the later cohort. These results are suspect, however, because only about 20 percent of the NLSY97 and NLSY79 samples have a surveyed sibling, and this sample may be highly selected.
} 
model 2) has been controlled for. ${ }^{12}$ Predicted effects of senior work hours for the 1997 cohort are much smaller and statistically insignificant (at the 5 percent level), until controlling for family characteristics (in model 3). Adding ability covariates raises the expected future wage gain from senior work experience a bit more, providing possible evidence of modest negative selection effects. In the specifications that include all covariates (model 5), the positive predicted effect of 20 hours per week of senior year employment on future wages is about twice as large for the NLSY79 sample as for the NLSY97 cohort (8.3 vs. 4.4 percent).

Table 5 presents results using different specifications of high school work experience. Model 1 controls for weekly employment hours during the sophomore and junior, as well as the senior year. ${ }^{13}$ Sophomore and junior work hours have statistically insignificant affects for both cohorts and the point estimates are small, suggesting that working 20 hours increases future wages by no more than 2.3 percent (although the predicted effect of senior year work is also small for the NLSY97). The positive predicted effect of senior year employment is somewhat attenuated for the NLSY79 sample when employment in other grades is controlled for: 5.9 percent for working 20 hours per week as a high school senior, versus an 8.3 percent premium in model 5 of table 4. Insignificant senior-year results for NLSY97 respondents are probably partially due to the correlation of work across high school years, and because the sample size shrinks almost 30 percent. $^{14}$

12 The robustness of these later specifications increases our confidence that the selection effects are well accounted for by the inclusion of demographic controls, since the results are insensitive to the addition of a variety of alternative potential sources of heterogeneity.

${ }^{13}$ We do not include a corresponding covariate for the freshman year because few freshmen work.

${ }^{14}$ Most of the sample size reduction occurs when the earlier high school years took place prior to the start of the NLSY work histories. 
Model 2 includes a quadratic in work-hours, allowing for nonlinearity in the effect of senior year employment. The hours squared term is statistically significant for the NLSY97 but not the NLSY79 sample, and in neither case suggests diminishing returns to senior year employment. In the third panel, senior year employment is categorized into $>0$ to $10,>10$ to 20 , and $>20$ hours per week, with no work the excluded reference group. These results indicate that adult wages increase monotonically with senior year work hours, and provide suggestive evidence of modest nonlinearities in the predicted effects. Despite this, little is lost by estimating linear specifications, and these are far easier to interpret. Therefore we focus on them in much of the remaining analysis.

The final panel of Table 5 controls for summer (before the senior year) as well as academic year employment. The former has a statistically significant positive predicted effect on future wages for the earlier but not the later cohort, and the estimated wage differentials are always smaller than for working during the senior year. As with school year employment, the return to summer work appears to have declined over time.

\section{A. Instrumental Variables Estimates}

We explored potential biases in the preceding results, due to unobserved characteristics, using an instrumental variables (IV) strategy, where high school employment was predicted by local labor market conditions during the high school years. The instruments included the county values of the unemployment rate, various population and density measures, the age distribution, percent with a high school education and college education, and per capital income. The data required to create these instruments were available in the NLSY's restricted geography-coded data, which we obtained permission to use. ${ }^{15}$ Additionally, we

\footnotetext{
${ }^{15}$ Past labor market conditions (i.e. the high school unemployment rate) may affect subsequent wages even adjusting for current labor market conditions (i.e. the unemployment rate). Beaudry and DiNardo (1991)
} 
followed, Neumark (2002) in estimating some models that controlled for cohort average unemployment rates, which may be less susceptible to bias caused by endogenous migration than individual unemployment rates.

Results from the first stage models, that predict early work experience, were generally as expected (e.g. lower unemployment rates were significantly positively associated with high school employment). However, while both sets of instruments were highly significant (at the .01 level), the corresponding Fstatistics ranged from 3.30 to 5.93, or well below the threshold of 10 recommended to avoid the problems of large standard errors and potentially biased estimates due to "weak instruments” (Nelson and Startz, 1990a,b; Bound, Jaeger, and Baker 1995; Staiger and Stock, 1997), reducing our confidence in the findings.

In the second-stage models, senior work year hours increased predicted adult wages for both NLSY79 specifications and for the NLSY97 specification that uses cohort unemployment rates. However, in three of the four comparisons, Hausman tests cannot reject the null hypothesis that the ordinary least squares (OLS) and IV results are not statistically different. The exception is when using cohort unemployment rates for NLSY79 respondents, where the IV estimates suggest larger beneficial effects for senior work than are predicted by OLS models.

\section{B. Other Robustness Tests}

The sample for our previous models includes unbalanced data from both the representative and supplemental NLSY samples, with sampling weights incorporated in the regressions. We explored the

show that the lowest previous unemployment rate (since beginning a job) affects wages even controlling for the current unemployment rate. Therefore, following Neumark (2002), we included also both the lowest previous unemployment rate and the current unemployment rate in our adult labor market outcomes models. 
implications of each of these choices. The first model in Table 6 repeats our estimates for the preferred specification in Table 4 (i.e. model 5) for ease of comparison. Next, we use a balanced sample, consisting of respondents providing valid work experience information for all high school years. As expected, the balanced samples are substantially smaller; nevertheless, we find significant, positive effects for both cohorts, although the point estimates are somewhat diminished: 20 extra hours of weekly work in the senior year predicts a wage premium of 6.0 percent for the NLSY79 sample and 3.5 percent for the NLSY97 sample. In model 3, we only include NLSY respondents who were part of the nationally representative cross section (e.g., the supplemental black and Hispanic oversamples are excluded) and in model 4 we do not weight the data. Neither of these alternatives appreciably changes the results.

\section{Other Labor Market Outcomes}

We examined the effects of early work experience on other adult economic outcomes including: the probability of being employed; the portion of weeks and hours worked, weeks unemployed, (the natural log of) annual and weekly earnings, and the receipt of health and retirement benefits in the main job held at the survey date. Results are presented in table 7. High school employment is predicted to have significantly positive effects on almost all outcomes, with larger estimated gains generally obtained for the earlier cohort. This again suggests that the beneficial consequences of high school work experience have diminished over time. However, cohort differences in the estimated impacts of high school employment are not always as large as for hourly wages. For example, working 20 hours (relative to not working) increases weeks and hours worked and annual earnings by 7.0, 9.6, and 18.1 percent for NLSY79 respondents compared to 4.7, 6.7, and 13.4 percent for NLSY97 sample. 


\section{Why Has the Benefit to Early Work Experience Decreased?}

To understand why the future labor market benefits of high school work experience have decreased over time, we next examine the roles of potential mediating factors including: occupational attainment, college attendance and graduation, post high school work experience, job tenure, and the probability that the individual remains on the same job held during the high school senior year. ${ }^{16}$ As a first step, we estimate how senior year employment is related to each of these factors. Here and below, we restrict the set of controls to those that are common to both cohorts. ${ }^{17}$ The results, summarized in Table 8 , show that there have been relatively small changes in most of these relationships. Senior year employment is positively related to blue collar employment, post-high school experience, adult tenure and the probability of remaining in the senior year job for both cohorts, although the last three of these associations may have weakened over time. The most important difference across cohorts is that high school work reduced the predicted probability of later holding a service job for NLSY79 respondents but increased it for their NLSY97 counterparts. Senior-year work hours have negative effects on the probability of graduating from college. The beneficial effects of high school employment on subsequent labor market conditions would therefore presumably be even larger than those observed if not for these negative effects on educational attainment.

${ }^{16}$ Occupation of the adult job (e.g., blue collar and service sector versus white collar) is defined using Morefield, Ribar, and Ruhm’s (2011) classification system.

${ }^{17}$ These include controls for gender, race/ethnicity, age, marital status, family size, cigarette smoking, BMI, region of residence, urban residence, the current and lowest unemployment rates, maternal and paternal education, living with both parents, native language, and religion. 
Table 9 returns to our main model, and examines how senior year employment is related to adult (log) wages, but with potential mediating factors now also controlled for (separately or in combination). Our focus is on the difference in the effects of student employment for the two cohorts. For example, model 1 shows our previously preferred specification (from model 5 in Table 4), with the aforementioned restriction that the covariates controlled for are common to both cohorts. Here, an extra 20 hours per of senior year work is predicted to increase log wages by 0.079 for the NLSY79 sample versus 0.035 for the NLSY97 group, implying a difference of 0.044 , as shown in the last row of the table. This implies a statistically significant 4.5 percent wage differential associated with 20 hours of student work, across the two periods.

Senior work hours may affect adult wages by influencing subsequent job occupation. Column (2) of Table 9 shows that blue-collar workers and service sector workers earn significantly less than their whitecollar counterparts; these differentials have changed modestly over time, by statistically insignificant amounts. What is more striking is that controlling for adult occupation reduces the early work experience coefficient differential by about a third (from 0.44 to 0.030 ), and eliminates its statistical significance. The primary reason is that senior year employment reduced the probability of ending up in a (relatively low paid) service job as an adult for the NLSY79 cohort, but increased it for the NSLY97 sample, thus offsetting a portion of the benefit of the early work that otherwise would have occurred for the later group. ${ }^{18}$

18 These estimates somewhat understate the role of occupations as a mediating factor. For instance, when controlling for 12 different occupation categories (as done by Morefield et al., 2011), the differential falls to 0.24. Conversely, when using just two categories - blue-collar vs. all other workers (see Fletcher, Sindelar, and Yamaguchi’s, 2009), or managers and professionals versus all others (Case and Deaton, 2005) - the differentials are 0.044 and 0.034 . 
Column (3) shows that the addition of controls for college attendance and graduation leaves the student employment wage differential essentially unaffected. This occurs because a slight increase in the predicted likelihood that student workers attend (but do not graduate from) college is offset by a small reduction in the returns from doing so.

Conversely, the role of high school employment on subsequent work experience is important. This occurs because student work has a lesser positive effect on subsequent employment experience for the later cohort, and the returns to this experience have also declined. As a result, controlling for weeks of post-high school work experience explains about 31 percent of the overall differential, which falls to 0.031 (see specification 4). ${ }^{19}$ Thus, subsequent work experience and adult occupation are of approximately equal importance as mediating factors.

Controlling for tenure (column 5) or whether the adult job is for the same employer as the last job held in high school (column 6) only modestly reduced the differential (to 0.41 and 0.40 respectively).

In model (7), we simultaneously control for occupation and subsequent experience, and in model (8), we include controls for all of the potential mediating factors together. With all of the mediating factors incorporated (model 8), the senior year employment coefficient is 0.050 for the 1979 cohort and is 0.033 for the 1997 respondents, implying a differential of 0.017, which is only around three-eighths as large as

\footnotetext{
${ }^{19}$ We estimated a number of alternative experience specifications, generally with comparable results. These included controlling for: (i) nonlinear effects with an additional squared experience covariate (the differential is 0.030), (ii) hours of post-high school employment (0.038), (iii) the proportion of post-high school weeks employed (0.029), (iv) weeks employed full-time (0.045), and ( $v$ ) weeks employed full-time and weeks employed part-time (0.038).
} 
without any mediating factors (column 1). ${ }^{20}$ Column (7) shows that essentially all of this is due to adult occupation and subsequent experience, where the differential is actually slightly smaller (at 0.014) than in model (8).

Table 10 provides information on how the results differ for subgroups stratified by sex and education. In the basic model (column 1 for males and column 3 for females), 20 hours of senior year employment are predicted to raise the wages of NLSY79 and NLSY97 men by seven and six percent, respectively, so that the coefficient differential for the two cohorts is a miniscule 0.007 . Conversely, the corresponding predicted return to high school work is around nine percent for the earlier cohort of females versus nothing for the later group, implying a differential of 0.092 . The addition of potential median factors explains 47 percent of the differential for females, reducing it to 0.048 (see model 4), while having no effect on that for men (as expected since there was no disparity in returns to begin with). The change for females occurs primarily because senior year work decreased future service sector employment for the 1979 cohort but increased it for the 1997 sample, and because student employment was slightly less strongly correlated with subsequent work experience for the 1997 cohort and the returns to such experience declined substantially over time.

${ }^{20}$ Specifically, with more comprehensive controls we were able to explain still more of the differential. We estimated models controlling for: (i) the occupation of the (last) high school job (the differential is 0.015), (ii) whether the occupation of the adult job and the high school job are the same (0.013), (iii) the adult job's industry (0.016), and (iv) the number of jobs held between high school and the adult job (0.016). We also grouped senior year work hours into the categories of 0 to 10,10 to 20 , and more than 20 hours of senioryear work. Secular changes in the student employment effects were concentrated among those working $\geq$ 20 hours per week, where the differential initially was 0.087 . Inclusion of the potential mediating factors reduced this to a statistically insignificant 0.049 . 
The results for educational subgroups show that the returns to high school employment are concentrated among the non-college bound, but that there has been a secular decline in these returns for both groups. Specifically, for the non-college bound NLSY79 sample, 20 hours of senior year employment were predicted to increase wages by around 13 percent, compared to seven percent for their NLSY97 counterparts, yielding a coefficient differential of 0.056 (column 5). For those attending college the corresponding predict effects and cohort differentials are 3.0 percent, 2.2 percent and 0.008 (column 7). Adding in the mediating factors reduces the expected returns in all cases, such that the coefficient declines by 0.021 for both the non-college and college groups (to 0.035 and -0.013 respectively), as shown in models (6) and (8).

\section{Discussion}

Work experience during the high school senior year continues to predict positive effects on labor market outcomes 5-11 years after the expected date of high school graduation, but these beneficial consequences have attenuated fairly dramatically over time. Our main regression specifications predict that the hourly wage premium from working 20 hours per week in the senior grade has fallen from 8.3 percent for NLSY79 respondents in 1987-1989 to 4.4 percent for the NLSY97 sample in 2008-2010. The benefits of student employment for the early cohort and the attenuation in these favorable effects over time are largely limited to women (versus men), for reasons that are not yet well understood and deserve study in future research.

Two other findings deserve mention. First, even though summer work may be less likely than school year employment to take time from academic pursuits, we uncover no evidence that it has more beneficial effects on future labor market outcomes. Second, while senior-year work experience significantly enhances adult labor market outcomes, sophomore and junior work hours typically do not. Differences in the effects of early work experience between the senior year and the sophomore and junior years could be 
due to Fair Labor Standards Act (FLSA) restrictions on the labor supply of youths or to restrictions placed on younger teens by their parents. ${ }^{21}$ Alternatively, the freelance jobs may be more common for this age group and have less beneficial effects than employee jobs.

These findings should be interpreted in light of at least two caveats. First, almost all of our analysis is restricted to high school graduates. To the extent that employment during the sophomore and junior years reduces the probability of completing high school, we might therefore be neglecting a negative effect of student employment. However, the estimated effects of sophomore- and junior-year work on high school graduation are small. Second, the failure to account for nonrandom selection into high school employment could introduce bias. However, the estimated effects of working in the senior year change little when additional covariates are included in the model, beyond a basic set of demographic characteristics, leading us to suspect that this is not a major issue. In addition, our instrumental variables models predict larger (albeit imprecisely measured) benefits than those obtained from our main specifications.

Our attempts to explain why the benefits of early work experience have attenuated over time indicate that at least five-eighths of the differential is due to mediation through adult occupation and subsequent work experience. Specifically, senior year employment reduced the likelihood that a member of the NLSY79 sample later ended up in a (typically low paid) service occupation, while this probability was increased for the NLSY97 cohort. In addition, high school job-holding is associated with higher levels of adult work experience for both cohorts, but the increase was smaller for NLSY97 students, at the same time that the returns to such experience (in the form of higher wages) declined. Conversely, virtually none of the differential between cohorts is explained by effects on educational attainment.

${ }^{21}$ The Fair Labor Standards Act (FLSA) of 1938 prohibits teens under 16 from working more than 3 hours on school days and 18 hours weekly in non-farm work. Those younger than 14 face additional restrictions, and some states have added supplemental prohibitions on teen and adolescent labor (Tyler, 2003). 


\section{References}

Aaronson, Daniel, Kyung-Hong Park, and Daniel Sullivan. (2006). “The Decline in Teen Labor Force Participation.” Economic Perspectives, 1Q: 2-18.

Arano, Kathleen, and Carl Parker. (2008). "How Does Employment Affect Academic Performance Among College Students.” Journal of Economics, 34 (2): 65-82.

Arrow, Kenneth J. (1973). "Higher Education as a Filter.” Journal of Public Economics, 2 (3): 193-216.

Bachman, Jerald G., Patrick M. O’Malley, John E. Schulenberg, Lloyd D. Johnston, Peter Freedman-Doan, and Emily E. Messersmith. (2008). The Education-Drug Use Connection: How Successes and Failures in School Relate to Adolescent Smoking, Drinking, Drug Use, and Delinquency. New York, NY: Lawrence Erlbaum Associated and Taylor \& Francis.

Bachman, Jerald G., Deborah J. Safron, Susan Rogala Sy, and John E. Schulenberg. (2003). “Wishing to Work: New Perspectives on How Adolescents' Part-Time Work Intensity is Linked with Educational Disengagement, Drug Use, and Other Problem Behaviors.” International Journal of Behavioral Development, 27 (4): 301-315.

Bachman, Jerald G., Jeremy Staff, Patrick M. O’Malley, John E. Schulenberg, and Peter Freedman-Doan. (2011). "Twelfth-Grade Student Work Intensity Linked to Later Educational Attainment and Substance Use: New Longitudinal Evidence.” Developmental Psychology, 47 (2): 344-363.

Bailey, T. R. (1995). Learning to Work: Employer Involvement in School-to-Work Transition Programs. Washington D. C.: The Brookings Institute.

Beaudry, Paul, and John DiNardo. (1991). "The Effect of Implicit Contracts on the Movement of Wages over the Business Cycle: Evidence from Micro Data.” Journal of Political Economy, 99 (4): 665-688.

Becker, Gary S. (1975). Human Capital (2 ${ }^{\text {nd }}$ ed.). Chicago, IL: University of Chicago Press.

Bishop, J. H. (1996). "Signaling the Competencies of High School Students to Employers.” In Resnick, L. B. and J. G. Wirt (eds.), Linking School and Work: Roles for Standards and Assessment. San Francisco: Jossey-Bass Publishers.

Bound, John, David A. Jaeger, and Regina M. Baker. (1995). "Problems with Instrumental Variables Estimation When the Correlation Between the Instruments and the Endogenous Explanatory Variable is Weak.” Journal of the American Statistical Association, 90 (430): 433-450.

Buscha, Franz, Arnaud Maurel, Lionel Page, and Stefan Speckesser. (2011). “The Effect of Employment while in High School on Educational Attainment: A conditional Difference-inDifference Approach.” Oxford Bulletin of Economics and Statistics, 74 (3): 1-17. 
Camarota, Stephen A. (2011). "Declining Summer Employment Among American Youth.” Report. Washington, D.C.: Center for Immigration Studies.

Carr, Rhoda V., James D. Wright, and Charles J. Brody. (1996). "Effects of High School Work Experience a Decade Later: Evidence from the National Longitudinal Survey." Sociology and Education, 69 (1): 66-81.

Case, Anne, and Angus Deaton. (2005). "Broken Down by Work and Sex: How Our Health Declines" in David A. Wise (ed.), Analyses in the Economics of Aging. Chicago, IL: University of Chicago Press, pp. 185-205.

D’Amico, Ronald. (1984). "Does Employment During High School Impair Academic Progress?” Sociology of Education, 57: 152-164.

DeSimone, Jeff. (2006). “Academic Performance and Part-Time Employment among High School Seniors." B.E. Journal of Economic Analysis and Policy: Topics in Economic Analysis and Policy, 6 (1): 1-34.

Eckstein, Zvi, and Kenneth I. Wolpin. (1999). "Why Youths Drop Out of High School: The Impact of Preferences, Opportunities, and Abilities.” Econometrica, 67 (6): 1295-1339.

Ehrenberg, Ronald G., and Daniel R. Sherman. (1987). "Employment While in College, Academic Achievement, and Postcollege Outcomes." The Journal of Human Resources, 22 (1): 123.

Fletcher, Jason M., Jody L. Sindelar, and Shintaro Yamaguchi. (2011). "Cumulative Effects of Job Characteristics on Health.” Health Economics, 20: 553-570.

Gottfredson, Denise C. (1985). "Youth Employment, Crime, and Schooling: A Longitudinal Study of a National Sample.” Developmental Psychology, 21 (3): 419-432.

Gottschalk, Peter, and Michael Hansen. (2003). "Is the Proportion of College Workers in Noncollege Jobs Increasing?” The Journal of Human Resources, 21 (2): 449-472.

Greenberger, Ellen and Laurence D. Steinberg. (1980). "Part-Time Employment of InSchool Youth: A Preliminary Assessment of Costs and Benefits." In A Review of Youth Employment, Problems, Programs, and Policies, by the U.S. Vice President's Task Force on Youth Employment. Washington, D.C.: U.S. Department of Labor, Employment, and Training Administration.

Greenberger, Ellen, and Laurence D. Steinberg. (1986). When Teenagers Work: The Psychological and Social Costs of Adolescent Employment. New York: Basic Books, Inc.

Hao, Lingxin, Nan M. Astone, and Andrew J. Cherlin. (2004). "Adolescents' Formal Employment and School Enrollment: Effects of State Welfare Policies." Journal of Policy Analysis and Management, 23 (4): 697-721. 
Hotz, V. Joseph, Lixin Xu, Marta Tienda, Avner Ahituv. (2002). “Are There Returns to the Wages of Young Men from Working While in School?” Review of Economics and Statistics, 84 (2): 221-236.

Hoynes, Hilary Williamson. (2000). "Local Labor Markets and Welfare Spells: Do Demand Conditions Matter?” Review of Economics and Statistics, 82 (3): 351-368.Light, Audrey. (1999). "High School Employment, High School Curriculum, and Post-School Wages." Economics of Education Review, 18: 291-309.

Kalenkoski, Charlene Marie, and Sabrina Wulff Pabilonia. (2009). "Does Working While in High School Reduce U.S. Study Time?” Social Indicators Research, 93 (1): 117-121.

Kalenkoski, Charlene Marie, and Sabrina Wulff Pabilonia. (2012). "Time to Work or Time to Play: The Effect of Student Employment on Homework, Sleep, and Screen Time.” Labour Economics, 19: 211-221.

LaLonde, Robert. (2003). “Employment and Training Programs.” In Means-Tested Transfer Programs in the United States (edited by Moffitt, Robert). Chicago, IL: University of Chicago Press.

Lee, Chanyoung, and Peter F. Orazem. (2010). "High School Employment, School Performance, and College Entry.” Economics of Education Review, 29: 29-39.

Leos-Urbel, Jacob. (2012). "What is a Summer Job Worth? The Impact of Summer Youth Employment on Academic Outcomes." Paper prepared for presentation at the Association for Public Policy Analysis and Management Fall Conference. New York University.

Light, Audrey. (2001). "In-School Work Experience and the Returns to Schooling." Journal of Labor Economics, 19 (1): 65-93.

Lillydahl, Jane H. (1990). “Academic Achievement and Part-Time Employment of High School Students.” Journal of Economic Education, 21 (3): 307-316.

Marsh, Herbert W. (1991). "Employment During High School: Character Building or a Subversion of Academic Goals?” Sociology of Education, 64 (3): 172-189.

Meyer, Robert H. and David A. Wise. (1982). "High School Preparation and Early Labor Force Experience.” In Freeman, Richard B., and David A. Wise (eds.), The Youth Labor Market Problem: Its Nature, Causes, and Consequences. Chicago: The University of Chicago Press.

Mincer, Jacob T. (1974). Schooling, Experience, and Earnings, New York: National Bureau of Economic Research.

Monahan, Kathryn C., Joanna M. Lee, and Laurence Steinberg. (2011). "Revisiting the Impact of Part-Time Work on Adolescent Adjustment: Distinguishing between Selection and Socialization Using Propensity Score Matching.” Child Development, 82 (1): 96-112. 
Montmarquette, Claude, Nathalie Viennot-Briot, and Marcel Dagenais. (2007). "Dropout, School Performance, and Working While in School.” Review of Economics and Statistics, 89 (4): 752-760.

Morefield, Brant, David C. Ribar, and Christopher J. Ruhm. (2011). "Socioeconomic Status and Health Across Generations and Over the Life Course.” The B.E. Journal of Economic Analysis and Policy, 11 (3): article 8.

Mortimer, Jeylan T. and Michael D. Finch. (1986). “The Effects of Part-Time Work on Adolescent Self-Concept and Achievement.” In Borman, Kathryn M., and Jane Reisman (eds.), Becoming a Worker. Norwood, New Jersey: Ablex Publishing Corporation.

Mortimer, Jeylan T., Michael D. Finch, Seongryeol Ryu, Michael J. Shanahan, Kathleen T. Call. (1996). "The Effects of Work Intensity on Adolescent Mental Health, Achievement, and Behavioral Adjustment: New Evidence from a Prospective Study.” Child Development, 67 (67): 1243-1261.

National Center for Education Statistics. (2012). “A Closer Look at High School Students in the United States Over the Last 20 Years.” U.S. Department of Education, Institute of Education Sciences, National Center for Education Statistics: http://nces.ed.gov/programs/coe/analysis/2012section3.asp.

Nelson, Charles R., and Richard Startz. (1990a). "Some Further Results on the Exact Small Sample Properties of the Instrumental Variables Estimator.” Econometrica, 58 (4): 967-976.

Nelson, Charles R., and Richard Startz. (1990b). "The Distribution of the Instrumental Variables Estimator and Its t-Ratio When the Instrument is a Poor One.” Journal of Business, 63 (1): S125-S140.

Neumark, David. (2002). "Youth Labor Markets in the United States: Shopping Around vs. Staying Put,” Review of Economics and Statistics, 84 (3): 462-482.

Neumark, David, and Mary Joyce. (2001). "Evaluating School-to-Work Programs Using the New NLSY.” The Journal of Human Resources, 36 (4): 666-702.

Oettinger, Gerald S. (1999). "Does High School Employment Affect High School Academic Performance?” Industrial and Labor Relations Review, 53 (1): 136-151.

Osterman, P. (1995). “Involving Employers in School-to-Work Programs.” In Bailey, T. R. (ed.), Learning to Work: Employer Involvement in School-to-Work Transition Programs. Washington, D. C.: The Brookings Institute.

Poczik, R. (1995). “Work-based Education and School Reform.” In Bailey, T. R. (ed.), Learning to Work: Employer Involvement in School-to-Work Transition Programs. Washington, D. C.: The Brookings Institute.

Rothstein, Donna S. (2007). "High School Employment and Youths' Academic Achievement.” The Journal of Human Resources, 42 (1): 194-213. 
Ruhm, Christopher J. (1997). “Is High School Employment Consumption or Investment?” Journal of Labor Economics, 15 (4): 735-776.

Sabia, Joseph J. (2009). "School-Year Employment and Academic Performance of Young Adolescents.” Economics of Education Review, 28 (2): 268-276.

Schill, William J., Rosemarie McCartin, and Katrina Meyer. (1985). "Youth Employment: Its Relationship to Academic and Family Variables.” Journal of Vocational Behavior, 26: 155-163.

Schoenhals, Mark, Marta Tienda, and Barbara Schneider. (1998). “The Educational and Personal Consequences of Adolescent Employment.” Social Forces, 77 (2): 723-762.

Smith, Christopher L. (2011). “Polarization, Immigration, and Education: What's Behind the Dramatic Decline in Youth Employment?” Working Paper. Washington, D.C.: Federal Reserve Board, Divisions of Research and Statistics and Monetary Affairs, Financial and Economics Discussion Series.

Smith, Christopher L. (2012). “The Impact of Low-Skilled Immigration on the Youth Labor Market.” Journal of Labor Economics, 30 (1): 55-89.

Spence, Michael A. (1973). “Job Market Signaling.” Quarterly Journal of Economics, 87 (3): 355-374.

Staff, Jeremy, John E. Schulenberg, and Jerald G. Bachman. (2010). “Adolescent Work Intensity, School Performance, and Academic Engagement.” Sociology of Education, 83 (3): 183200.

Staiger, Douglas, and James H. Stock. (1997). “Instrumental Variables regression with Weak Instruments.” Econometrica, 65 (3): 557-586.

Steel, Lauri. (1991). "Early Work Experience Among White and Non-White Youths: Implications for Subsequent Enrollment and Employment.” Youth and Society, 22 (4): 419-447.

Steinberg, Laurence, and Sanford M. Dornbusch. (1991). "Negative Correlated of Part-Time Employment During Adolescence: Replication and Elaboration.” Developmental Psychology, 27 (2): 304-313.

Steinberg, Laurence, Suzanne Fegley, and Sanford M. Dornbusch. (1993). "Negative Impact of Part-Time Work on Adolescent Adjustment: Evidence From a Longitudinal Study.” Developmental Psychology, 29 (2): 171-180.

Steinberg, Laurence, Ellen Greenberger, Laurie Garduque, and Sharon McAuliffe. (1982). "High School Students in the Labor Force: Some Costs and Benefits to Schooling and Learning." Education Evaluation and Policy Analysis, 4 (3): 363-372.

Steinberg, Laurence, Ellen Greenberger, Laurie Garduque, Mary Ruggiero, and Alan Vaux. (1982). “Effects of Working on Adolescent Development.” Developmental Psychology, 18 (3): 385-395. 
Stephenson, Jr., Stanley P. (1981). "In-School Labour Force Status and Post-School Wage Rates of Young Men.” Applied Economics, 13 (3): 279-302.

Stern, David, Neal Finkelstein, Miguel Urquiola, and Helen Cagampang. (1997). "What Difference Does it Make if School and Work are Connected? Evidence on Co-operative Education in the United States.” Economics of Education Review, 16 (3): 213-229.

Stern, David, and Yoshi-fumi Nakata. (1989). “Characteristics of High School Students' Paid Jobs, and Employment Experience After Graduation.” In Stern, David and Dorothy Eichorn (eds.), Adolescence and Work: Influences of Social Structure, Labor Markets, and Culture. Hillsdale, New Jersey: Lawrence Erlbaum Associates, Publishers.

Stinebrickner, Ralph, and Todd R. Stinebrickner. (2003). "Working During School and Academic Performance.” Journal of Labor Economics, 21(2): 473-491.

Sum, Andrew, Paul Harrington, and Ishwar Khatiwada. (2006). "The Impact of New Immigrants on Young Native-Born Workers, 2000-2005.” Backgrounder, September: 1-12.

Tyler, John H. (2003). "Using State Child Labor Laws to Identify the Effect of School-Year Work on High School Achievement,” Journal of Labor Economics, 21 (2): 381-408.

Warren, John Robert. (2002). "Reconsidering the Relationship between Student Employment and Academic Outcomes: A New Theory and Better Data.” Youth and Society, 33 (3): 366-393.

Warren, John Robert, and Jennifer C. Lee. (2003). "The Impact of Adolescent Employment on High School Dropout: Differences by Individual and Labor-Market Characteristics.” Social Science Research, 32 (1): 98-128.

Warren, John Robert, Paul C. LePore, and Robert D. Mare. (2000). "Employment During High School: Consequences for Students' Grades in Academic Courses.” American Educational Research Journal, 37 (4): 943-969. 
Table 1: Descriptive Statistics: Early Work Experience

\begin{tabular}{|c|c|c|}
\hline & $\frac{\text { NLSY79 (1987- }}{1989)}$ & $\begin{array}{l}\frac{\text { NLSY97 (2008- }}{2010)} \\
\end{array}$ \\
\hline \multicolumn{3}{|l|}{ Early Work Experience } \\
\hline \multirow[t]{2}{*}{ Employed (=1 if employed during HS) } & 0.817 & 0.847 \\
\hline & $(0.006)$ & $(0.005)$ \\
\hline \multirow[t]{2}{*}{ Sophomore Hours (average hours per week) } & 4.704 & 4.835 \\
\hline & (0.189) & $(0.157)$ \\
\hline \multirow[t]{2}{*}{ Junior Hours (average hours per week) } & 8.377 & 9.236 \\
\hline & $(0.188)$ & $(0.168)$ \\
\hline \multirow{2}{*}{ Senior Hours (average hours per week) } & 13.325 & 13.810 \\
\hline & $(0.200)$ & $(0.198)$ \\
\hline \multirow[t]{2}{*}{ Senior Hours $=0$ per week } & 0.252 & 0.239 \\
\hline & $(0.007)$ & $(0.006)$ \\
\hline \multirow{2}{*}{ Senior Hours $=(0-10]$ per week } & 0.209 & 0.217 \\
\hline & $(0.006)$ & $(0.006)$ \\
\hline \multirow[t]{2}{*}{ Senior Hours $=(10-20]$ per week } & 0.234 & 0.234 \\
\hline & $(0.007)$ & $(0.006)$ \\
\hline \multirow[t]{2}{*}{ Senior Hours $=(20-\infty]$ per week } & 0.302 & 0.307 \\
\hline & $(0.007)$ & $(0.007)$ \\
\hline \multirow[t]{2}{*}{ Senior Weeks Worked (percent) } & 0.559 & 0.592 \\
\hline & $(0.007)$ & $(0.006)$ \\
\hline \multirow[t]{2}{*}{ Summer Hours (average hours per week) } & 20.048 & 19.047 \\
\hline & $(0.261)$ & $(0.244)$ \\
\hline Sample Size & 3,637 & 3,925 \\
\hline
\end{tabular}

Note: Weighted means are provided with standard errors in parentheses. 
Table 2: Descriptive Statistics: Subsequent Labor Market Outcomes

\begin{tabular}{lcc}
\hline & NLSY79 (1987-1989) & NLSY97 (2008-2010) \\
\hline Hourly Wages (dollars) & 17.127 & 17.300 \\
Employed (=1 employed as adult) & $(0.206)$ & $(0.203)$ \\
Weeks Worked (annual weeks/52) & 0.944 & 0.928 \\
& $(0.003)$ & $(0.004)$ \\
Hours Worked (annual hours/52) & 0.802 & 0.787 \\
Unemployed Weeks (annual weeks/52) & $(0.004)$ & $(0.005)$ \\
& 32.313 & 30.296 \\
Weekly Wages (dollars) & $(0.241)$ & $0.239)$ \\
Annual Earnings (thousands of dollars) & 0.031 & 0.057 \\
& $(0.001)$ & 668.740 \\
Medical Benefits (=1 if in receipt) & 634.454 & $(6.975)$ \\
& $(46.989)$ & 29.787 \\
Retirement Benefits (=1 if in receipt) & 28.605 & $(0.325)$ \\
Education (in years) & $(0.353)$ & 0.716 \\
College Degree (=1 if college education) & 0.759 & $(0.006)$ \\
& $(0.007)$ & 0.539 \\
& 0.564 & $(0.007)$ \\
& $(0.007)$ & 14.617 \\
& 13.627 & $(0.036)$ \\
& $(0.039)$ & 0.416 \\
& 0.268 & 3,925 \\
\hline
\end{tabular}

Note: Weighted means are provided with standard errors in parentheses. Dollar figures are adjusted for inflation to year-2012 dollars. Adult economic outcomes are averaged over the indicated threesurvey year period. 
Table 3: Associations Between Student Work Experience and Subsequent Labor Market Outcomes

\begin{tabular}{|c|c|c|c|c|c|c|c|c|}
\hline \multirow[b]{2}{*}{ Early Work Experience } & \multicolumn{4}{|c|}{ NLSY79 (1987-1989) } & \multicolumn{4}{|c|}{ NLSY97 (2008-2010) } \\
\hline & $\mathrm{N}$ & Wage & Weeks & College & $\mathrm{N}$ & Wage & Weeks & College \\
\hline Senior Hours $=0$ & 1133 & 15.583 & 0.732 & 0.257 & 1047 & 16.991 & 0.752 & 0.433 \\
\hline Senior Hours $=(0-10]$ & 719 & 17.189 & 0.785 & 0.318 & 834 & 17.505 & 0.773 & 0.497 \\
\hline Senior Hours = $(10-20]$ & 808 & 17.010 & 0.827 & 0.326 & 870 & 17.378 & 0.810 & 0.467 \\
\hline Senior Hours $=(20-\infty]$ & 977 & 18.403 & 0.854 & 0.200 & 1174 & 17.328 & 0.805 & 0.307 \\
\hline Summer Hours $=0$ & 1183 & 14.583 & 0.708 & 0.199 & 1118 & 17.256 & 0.706 & 0.370 \\
\hline Summer Hours = $(0-10]$ & 301 & 16.405 & 0.827 & 0.313 & 419 & 16.904 & 0.791 & 0.521 \\
\hline Summer Hours = $(10-20]$ & 509 & 18.451 & 0.838 & 0.363 & 654 & 17.180 & 0.826 & 0.507 \\
\hline Summer Hours $=(20-\infty]$ & 1,640 & 18.153 & 0.838 & 0.270 & 1725 & 17.442 & 0.816 & 0.381 \\
\hline Sample Size & \multicolumn{4}{|c|}{3,637} & \multicolumn{4}{|c|}{3,925} \\
\hline
\end{tabular}

Note: Weighted means are provided. Dollar figures are adjusted for inflation to year-2012 dollars. N is number of observations in a particular early work experience category. Wage is the adult hourly wage in dollars. Weeks is average portion of annual weeks worked.

College is an indicator for subsequently obtaining a college degree. Adult wages and weeks worked are averaged over the indicated threesurvey year period. 
Table 4: Regression-Adjusted Estimated Effects of Early Work Experience on Log Hourly Wages

\begin{tabular}{|c|c|c|c|c|c|}
\hline & Model 1 & Model 2 & Model 3 & $\underline{\text { Model } 4}$ & $\underline{\text { Model } 5}$ \\
\hline Time Period & \multicolumn{5}{|c|}{ NLSY79 Respondents in 1987-1989 } \\
\hline \multirow[t]{2}{*}{$\overline{\text { Senior Hours }}$} & $0.114^{* * *}$ & $0.074 * * *$ & $0.074 * * *$ & $0.080 * * *$ & $0.080 * * *$ \\
\hline & $(0.013)$ & $(0.013)$ & $(0.013)$ & $(0.013)$ & $(0.013)$ \\
\hline \multirow[t]{2}{*}{ Observations } & 3,336 & 3,336 & 3,336 & 3,336 & 3,336 \\
\hline & \multicolumn{5}{|c|}{ NLSY97 Respondents in 2008-2010 } \\
\hline \multirow[t]{2}{*}{ Senior Hours } & $0.025 *$ & 0.020 & $0.034 * *$ & $0.042 * *$ & $0.043 * * *$ \\
\hline & $(0.014)$ & $(0.015)$ & $(0.015)$ & $(0.015)$ & $(0.015)$ \\
\hline Observations & 3,629 & 3,629 & 3,629 & 3,629 & 3,629 \\
\hline \multicolumn{6}{|l|}{ Covariates } \\
\hline$\overline{\text { Demographic }}$ & & $X$ & $X$ & $X$ & $X$ \\
\hline Family & & & $\mathrm{X}$ & $\mathrm{X}$ & $X$ \\
\hline Ability & & & & $\mathrm{X}$ & $\mathrm{X}$ \\
\hline School & & & & & $X$ \\
\hline
\end{tabular}

Note: ${ }^{* * *} \mathrm{p}<0.01,{ }^{* *} \mathrm{p}<0.05,{ }^{*} \mathrm{p}<0.1$. Standard errors are in parentheses. The table shows estimated coefficients on weekly senior grade work

hours divided by 20. The demographic covariates include controls for gender, race/ethnicity, age, marital status, family size, region of residence,

urbanicity, the current unemployment rate, and the lowest unemployment rate. The family background characteristics include mother's and father's education, living with both parents, whether English was spoken, town size, in both cohorts, as well as religious affiliation, and church attendance in the NLSY97 and whether the household had a magazine subscription, took a newspaper, had a library card, and the number of siblings in the NLSY79. Ability for NLSY97 respondents is the ASVAB score and for NLSY79 respondents is the AFQT score. We also include $8^{\text {th }}$ grade GPA as an ability measure for NLSY97 respondents. The covariate block of school characteristics and experiences includes the student's high school 
program of study (general, college preparatory, vocational, or combination), number of math and science courses taken, school type (public, private, or parochial), size, and student-teacher ratio for NLSY97 respondents. For the NLSY79 sample, this includes program of study (vocational, commercial, college preparatory, or general), school type (public or private), and student perceptions of boredom, safety, and satisfaction with school. The school experiences vector contains measures of cigarette-smoking and body mass index (BMI) for both NLSY samples. Wages are measured in logs and are averaged over three survey years. 
Table 5: Regression-Adjusted Estimated Effects of Early Work Experience on Log Hourly Wages, Different Specifications of Early Work Experience

\begin{tabular}{|c|c|c|}
\hline & NLSY79 (1987-1989) & NLSY97 (2008-2010) \\
\hline \multicolumn{3}{|l|}{ Model 1} \\
\hline \multirow[t]{2}{*}{ Sophomore Hours } & -0.041 & -0.014 \\
\hline & $(0.032)$ & $(0.027)$ \\
\hline \multirow{2}{*}{ Junior Hours } & 0.021 & 0.023 \\
\hline & (0.031) & (0.025) \\
\hline \multirow[t]{2}{*}{ Senior Hours } & $0.057 * *$ & 0.028 \\
\hline & $(0.023)$ & (0.024) \\
\hline Observations & 1,559 & 2,586 \\
\hline \multicolumn{3}{|l|}{ Model 2} \\
\hline \multirow[t]{2}{*}{ Senior Hours } & 0.046 & -0.027 \\
\hline & $(0.041)$ & $(0.045)$ \\
\hline \multirow[t]{2}{*}{ Senior Hours Squared } & 0.020 & $0.041 *$ \\
\hline & $(0.023)$ & $(0.025)$ \\
\hline p-value & 0.001 & 0.003 \\
\hline Observations & 3,336 & 3,629 \\
\hline \multicolumn{3}{|l|}{ Model 3} \\
\hline \multirow{2}{*}{ Senior Hours $=(0-10]$} & 0.025 & 0.016 \\
\hline & $(0.023)$ & $(0.026)$ \\
\hline \multirow{2}{*}{ Senior Hours $=(10-20]$} & $0.047^{* *}$ & 0.023 \\
\hline & $(0.022)$ & $(0.025)$ \\
\hline \multirow[t]{2}{*}{ Senior Hours $=(20-\infty]$} & $0.127^{* * *}$ & $0.055^{* *}$ \\
\hline & $(0.021)$ & $(0.024)$ \\
\hline p-value & 0.001 & 0.142 \\
\hline Observations & 3,336 & 3,629 \\
\hline \multicolumn{3}{|l|}{ Model 4} \\
\hline \multirow[t]{2}{*}{$\overline{\text { Senior Hours }}$} & $0.055 * * *$ & $0.033^{* *}$ \\
\hline & $(0.015)$ & $(0.017)$ \\
\hline \multirow{2}{*}{ Summer Hours } & $0.044 * * *$ & 0.017 \\
\hline & $(0.011)$ & $(0.014)$ \\
\hline Observations & 3,336 & 3,629 \\
\hline
\end{tabular}

Note: ${ }^{* * *} \mathrm{p}<0.01,{ }^{* *} \mathrm{p}<0.05,{ }^{*} \mathrm{p}<0.1$. Standard errors are in parentheses. Table shows estimated coefficients on the indicated early work experience covariates. The models include the demographic, 
family, ability, and school covariates. Dollar figures are adjusted for inflation to year-2012 dollars. Wages are in logs and averaged over three survey years. 
Table 6: Regression-Adjusted Estimated Effects of Early Work Experience on Wages: Robustness Tests

\begin{tabular}{|c|c|c|c|c|}
\hline & $\frac{\text { Model 1: Original }}{\underline{\text { Results }}}$ & $\frac{\text { Model 2: Balanced }}{\underline{\text { Sample }}}$ & $\begin{array}{c}\frac{\text { Model 3: }}{\text { Nationally }} \\
\frac{\text { Representative }}{\text { Sample }}\end{array}$ & $\begin{array}{l}\frac{\text { Model 4: }}{\underline{\text { No }}} \\
\text { Weights }\end{array}$ \\
\hline & \multicolumn{4}{|c|}{ NLSY79 Respondents in 1987-1989 } \\
\hline Senior Hours & $\begin{array}{c}0.080 * * * \\
(0.013)\end{array}$ & $\begin{array}{c}0.058 * * * \\
(0.019)\end{array}$ & $\begin{array}{c}0.080 * * * \\
(0.016)\end{array}$ & $\begin{array}{c}0.080 * * * \\
(0.013)\end{array}$ \\
\hline \multirow[t]{2}{*}{ Observations } & 3,336 & 1,559 & 2,168 & 3,336 \\
\hline & \multicolumn{4}{|c|}{ NLSY97 Respondents in 2008-2010 } \\
\hline Senior Hours & $\begin{array}{c}0.043^{* * *} \\
(0.015)\end{array}$ & $\begin{array}{c}0.035 * * \\
(0.017)\end{array}$ & $\begin{array}{c}0.048 * * * \\
(0.017)\end{array}$ & $\begin{array}{l}0.035^{* *} \\
(0.014)\end{array}$ \\
\hline Observations & 3,629 & 2,586 & 2,811 & 3,629 \\
\hline
\end{tabular}

Note: $* * * \mathrm{p}<0.01, * * \mathrm{p}<0.05, * \mathrm{p}<0.1$. Standard errors are in parentheses. Table shows estimated

coefficients on weekly senior year work hours divided by 20. Models include the demographic, family, ability, and school covariates. Dollar figures are adjusted for inflation to year-2012 dollars. Wages are in logs and averaged over three survey years. 
Table 7: Regression-Adjusted Estimated Effects of Early Work Experience on Adult Outcomes

\begin{tabular}{|c|c|c|c|c|c|c|c|c|}
\hline & $\begin{array}{l}\text { Model 1: } \\
\text { Employed }\end{array}$ & $\begin{array}{l}\frac{\text { Model 2: }}{\text { Weeks }} \\
\underline{\text { Worked }}\end{array}$ & $\begin{array}{l}\text { Model 3: } \\
\underline{\text { Hours }} \\
\text { Worked } \\
\end{array}$ & $\begin{array}{c}\frac{\text { Model 4: }}{\text { Weeks }} \\
\text { Unemployed } \\
\end{array}$ & $\begin{array}{l}\text { Model 5: } \\
\underline{\text { Log Annual }} \\
\underline{\text { Earnings }}\end{array}$ & $\begin{array}{c}\frac{\text { Model 6: }}{\text { Log Weekly }} \\
\underline{\text { Wage }}\end{array}$ & $\begin{array}{l}\frac{\text { Model 7: }}{\text { Health }} \\
\underline{\text { Benefits }}\end{array}$ & $\begin{array}{c}\text { Model 8: } \\
\text { Retirement } \\
\text { Benefits } \\
\end{array}$ \\
\hline & \multicolumn{8}{|c|}{ NLSY79 Respondents in 1987-1989 } \\
\hline Senior Hours & $\begin{array}{c}0.234^{* * *} \\
(0.076)\end{array}$ & $\begin{array}{c}0.053^{* * *} \\
(0.007)\end{array}$ & $\begin{array}{c}0.072^{* * *} \\
(0.008)\end{array}$ & $\begin{array}{c}-0.013 * * \\
(0.002)\end{array}$ & $\begin{array}{c}0.166^{* *} \\
(0.021)\end{array}$ & $\begin{array}{c}0.089 * * * \\
(0.016)\end{array}$ & $\begin{array}{c}0.063^{* *} \\
(0.010)\end{array}$ & $\begin{array}{c}0.043^{* * *} \\
(0.013)\end{array}$ \\
\hline \multirow[t]{2}{*}{ Observations } & 3,637 & 3,637 & 3,637 & 3,637 & 3,313 & 3,299 & 3,194 & 3,031 \\
\hline & \multicolumn{8}{|c|}{ NLSY97 Respondents in 2008-2010 } \\
\hline Senior Hours & $\begin{array}{c}0.039 \\
(0.054)\end{array}$ & $\begin{array}{c}0.035^{* * * *} \\
(0.007)\end{array}$ & $\begin{array}{c}0.048 * * * \\
(0.009)\end{array}$ & $\begin{array}{c}-0.007 * * \\
(0.003)\end{array}$ & $\begin{array}{c}0.125^{* * *} \\
(0.021)\end{array}$ & $\begin{array}{c}0.066^{* * *} \\
(0.019)\end{array}$ & $\begin{array}{c}0.036 * * \\
(0.011)\end{array}$ & $\begin{array}{c}0.036^{* *} \\
(0.012)\end{array}$ \\
\hline Observations & 3,925 & 3,925 & 3,925 & 3,925 & 3,479 & 3,380 & 3,418 & 3,418 \\
\hline
\end{tabular}

Note: ${ }^{* * *} \mathrm{p}<0.01,{ }^{* *} \mathrm{p}<0.05,{ }^{*} \mathrm{p}<0.1$. Standard errors are in parentheses. Table shows estimated

coefficients on weekly senior year work hours divided by 20. Models include the demographic, family, ability, and school covariates. Dollar figures are adjusted for inflation to year-2012 dollars. Wages and earnings are in logs. Weeks and hours worked are annual measures divided by 52 and 52*40, respectively. Health and retirement benefits equal the probability of receipt. All economic outcomes are averaged over three survey years. 
Table 9: Estimated Effects of Early Work Experience on Log Hourly Wages, With Mediating Factors

\begin{tabular}{|c|c|c|c|c|c|c|c|c|}
\hline Specification & $(1)$ & $\underline{(2)}$ & $(3)$ & $(4)$ & $\underline{(5)}$ & $\underline{(6)}$ & $(7)$ & $(8)$ \\
\hline \multicolumn{9}{|l|}{ NLSY79 Cohort } \\
\hline \multirow[t]{2}{*}{ Senior Hours } & $0.079 * * *$ & $0.073 * * *$ & $0.096 * * *$ & $0.042 * * *$ & $0.065^{* * *}$ & $0.069 * * *$ & $0.037^{* * *}$ & $0.050^{* * *}$ \\
\hline & $(0.013)$ & $(0.013)$ & $(0.013)$ & $(0.013)$ & $(0.013)$ & $(0.013)$ & $(0.013)$ & $(0.013)$ \\
\hline \multirow[t]{2}{*}{ Blue-Collar } & - & $-0.087^{* * *}$ & - & - & - & - & $-0.094^{* * *}$ & -0.015 \\
\hline & - & $(0.020)$ & - & - & - & - & $(0.020)$ & $(0.020)$ \\
\hline \multirow[t]{2}{*}{ Service } & - & $-0.277^{* * *}$ & - & - & - & - & $-0.268 * * *$ & $-0.195 * * *$ \\
\hline & - & $(0.023)$ & - & - & - & - & $(0.023)$ & $(0.023)$ \\
\hline \multirow[t]{2}{*}{ Some College } & - & - & $0.081^{* * *}$ & - & - & - & - & $0.077^{* * *}$ \\
\hline & - & - & (0.019) & - & - & - & - & (0.019) \\
\hline \multirow[t]{2}{*}{ College Graduate } & - & - & $0.269 * * *$ & - & - & - & - & $0.282^{* * *}$ \\
\hline & - & - & (0.021) & - & - & - & - & $(0.022)$ \\
\hline \multirow[t]{2}{*}{ Post-High School Experience } & - & - & - & $0.048^{* * *}$ & - & - & $0.047^{* * *}$ & $0.047^{* * *}$ \\
\hline & - & - & - & $(0.005)$ & - & - & $(0.005)$ & $(0.006)$ \\
\hline \multirow[t]{2}{*}{ Adult Tenure } & - & - & - & - & $0.044^{* * *}$ & - & - & $0.030 * * *$ \\
\hline & - & - & - & - & $(0.005)$ & - & - & $(0.005)$ \\
\hline \multirow[t]{2}{*}{ Same Job } & - & - & - & - & - & $0.053^{* *}$ & - & -0.015 \\
\hline & - & - & - & - & - & (0.017) & - & $(0.017)$ \\
\hline \multicolumn{9}{|l|}{ NLSY97 Cohort } \\
\hline \multirow[t]{2}{*}{ Senior Hours } & $0.035^{*}$ & $0.043^{* * *}$ & $0.053^{* * *}$ & 0.011 & 0.024 & $0.029 * *$ & 0.023 & $0.033^{* *}$ \\
\hline & $(0.015)$ & $(0.014)$ & $(0.014)$ & $(0.014)$ & $(0.014)$ & $(0.014)$ & $(0.014)$ & $(0.014)$ \\
\hline \multirow[t]{2}{*}{ Blue-Collar } & - & $-0.065^{* *}$ & - & - & - & - & $-0.070^{* * *}$ & 0.001 \\
\hline & - & $(0.026)$ & - & - & - & - & $(0.026)$ & $(0.027)$ \\
\hline \multirow[t]{2}{*}{ Service } & - & $-0.332 * * *$ & - & - & - & - & $-0.325^{* * *}$ & $-0.262 * * *$ \\
\hline & - & $(0.024)$ & - & - & - & - & $(0.024)$ & $(0.024)$ \\
\hline \multirow[t]{2}{*}{ Some College } & - & - & $0.071^{* *}$ & - & - & - & - & $0.067^{* * *}$ \\
\hline & - & - & (0.023) & - & - & - & - & $(0.023)$ \\
\hline \multirow[t]{2}{*}{ College Graduate } & - & - & $0.285^{* * *}$ & - & - & - & - & $0.253^{* * *}$ \\
\hline & - & - & $(0.024)$ & - & - & - & - & $(0.025)$ \\
\hline \multirow[t]{2}{*}{ Post-High School Experience } & - & - & - & $0.037^{* * *}$ & - & - & $0.032 * * *$ & $0.023 * * *$ \\
\hline & - & - & - & $(0.006)$ & - & - & $(0.005)$ & $(0.006)$ \\
\hline \multirow[t]{2}{*}{ Adult Tenure } & - & - & - & - & $0.043^{* * *}$ & - & - & $0.035^{* * *}$ \\
\hline & - & - & - & - & $(0.006)$ & - & - & $(0.006)$ \\
\hline \multirow[t]{2}{*}{ Same Job } & - & - & - & - & - & $0.034^{*}$ & - & -0.003 \\
\hline & - & - & - & - & - & (0.019) & - & $(0.021)$ \\
\hline \multirow[t]{2}{*}{ Difference $\left(\mathrm{H}_{1}-\mathrm{H}_{2}\right)$} & $0.044^{* *}$ & 0.030 & $0.043^{* *}$ & 0.031 & $0.041^{* *}$ & $0.040^{* *}$ & 0.014 & 0.017 \\
\hline & $(0.019)$ & $(0.019)$ & $(0.019)$ & $(0.020)$ & $(0.019)$ & $(0.019)$ & $(0.019)$ & $(0.019)$ \\
\hline
\end{tabular}


Note: ${ }^{* *} \mathrm{p}<0.01,{ }^{* *} \mathrm{p}<0.05, * \mathrm{p}<0.1$. Standard errors are in parentheses. There are 3,336 observations in the 1987-1989 NLSY79 sample and 3,629 observations in the 2008-2010 NLSY97 sample. Table shows estimated coefficients on senior year weekly work hours divided by 20 and the potential mediating factors. White-collar occupations and a high school degree are the excluded categories. Models include the demographic and supplemental family covariates common to both NLSY cohorts. Dollar figures are adjusted for inflation to year-2012 dollars. Wages are in logs and averaged over three survey years. 
Table 10: Subgroup Estimates of Effects of Early Work Experience on Log Hourly Wages

\begin{tabular}{|c|c|c|c|c|c|c|c|c|}
\hline Specification & (1) & (2) & (3) & (4) & (5) & (6) & (7) & (8) \\
\hline NLSY79 Cohort & \multicolumn{2}{|c|}{ Males } & \multicolumn{2}{|c|}{ Females } & \multicolumn{2}{|c|}{ No College } & \multicolumn{2}{|c|}{$\underline{\text { Some College }}$} \\
\hline \multirow{2}{*}{ Senior Hours } & $0.069 * * *$ & $0.057^{* * *}$ & $0.088^{* * *}$ & $0.049 * *$ & $0.128 * * *$ & $0.080^{* * *}$ & 0.030 & 0.003 \\
\hline & $(0.017)$ & (0.017) & $(0.020)$ & (0.019) & $(0.017)$ & (0.016) & $(0.020)$ & $(0.021)$ \\
\hline \multirow[t]{2}{*}{ Blue-Collar } & - & -0.001 & - & -0.056 & - & 0.019 & - & $-0.138 * * *$ \\
\hline & - & $(0.026)$ & - & $(0.037)$ & - & $(0.025)$ & - & $(0.035)$ \\
\hline \multirow{2}{*}{ Service } & - & $-0.148 * * *$ & - & $-0.218 * * *$ & - & $-0.187 * * *$ & - & $-0.245 * * *$ \\
\hline & - & $(0.036)$ & - & $(0.030)$ & - & $(0.028)$ & - & $(0.039)$ \\
\hline \multirow[t]{2}{*}{ Some College } & - & $0.082 * * *$ & - & $0.064 * *$ & - & - & - & - \\
\hline & - & (0.027) & - & (0.027) & - & - & - & - \\
\hline \multirow[t]{2}{*}{ College Graduate } & - & $0.242 * * *$ & - & $0.317^{* * *}$ & - & - & - & - \\
\hline & - & $(0.032)$ & - & $(0.030)$ & - & - & - & - \\
\hline \multirow{2}{*}{ Post-High School Exp. } & - & $0.034 * * *$ & - & $0.050 * * *$ & - & $0.064 * * *$ & - & $0.019 * *$ \\
\hline & - & $(0.008)$ & - & $(0.008)$ & - & $(0.008)$ & - & $(0.009)$ \\
\hline \multirow[t]{2}{*}{ Adult Tenure } & - & 0.008 & - & $0.055^{* * *}$ & - & $0.017^{* *}$ & - & $0.046^{* * *}$ \\
\hline & - & $(0.007)$ & - & $(0.008)$ & - & $(0.006)$ & - & $(0.010)$ \\
\hline \multirow[t]{2}{*}{ Same Job } & - & -0.014 & - & -0.007 & - & -0.026 & - & 0.001 \\
\hline & - & $(0.024)$ & - & $(0.025)$ & - & $(0.025)$ & - & $(0.025)$ \\
\hline Observations & 1,636 & 1,636 & 1,700 & 1,700 & 1,713 & 1,713 & 1,632 & 1,632 \\
\hline \multicolumn{9}{|l|}{ NLSY97 Cohort } \\
\hline \multirow[t]{2}{*}{ Senior Hours } & $0.062^{* * *}$ & $0.054^{* * *}$ & -0.004 & 0.001 & $0.072^{* * *}$ & $0.045^{*}$ & 0.022 & 0.016 \\
\hline & (0.019) & $(0.020)$ & $(0.021)$ & $(0.021)$ & $(0.024)$ & $(0.023)$ & $(0.018)$ & $(0.018)$ \\
\hline \multirow[t]{2}{*}{ Blue-Collar } & - & -0.007 & - & -0.047 & - & 0.028 & - & $-0.073 * *$ \\
\hline & & $(0.033)$ & & $(0.058)$ & & $(0.043)$ & & $(0.036)$ \\
\hline \multirow[t]{2}{*}{ Service } & - & $-0.276 * * *$ & - & $-0.238 * * *$ & - & $-0.172 * * *$ & - & $-0.334 * * *$ \\
\hline & & (0.039) & & $(0.031)$ & & $(0.044)$ & & $(0.030)$ \\
\hline \multirow[t]{2}{*}{ Some College } & - & 0.037 & - & $0.105^{* * *}$ & - & - & - & - \\
\hline & & $(0.033)$ & & $(0.033)$ & & & & \\
\hline \multirow[t]{2}{*}{ College Graduate } & - & $0.186^{* * *}$ & - & $0.320 * * *$ & - & - & - & - \\
\hline & & $(0.033)$ & & $(0.035)$ & & & & \\
\hline \multirow[t]{2}{*}{ Post-High School Exp. } & - & $0.024^{* *}$ & - & $0.017^{*}$ & - & $0.028^{* *}$ & - & $0.017^{* *}$ \\
\hline & & (0.009) & & (0.009) & & $(0.012)$ & & $(0.008)$ \\
\hline \multirow[t]{2}{*}{ Adult Tenure } & - & $0.029 * * *$ & - & $0.043^{* * *}$ & - & $0.060^{* * *}$ & & $0.020^{* *}$ \\
\hline & & $(0.008)$ & & $(0.009)$ & & $(0.010)$ & & $(0.008)$ \\
\hline \multirow[t]{2}{*}{ Same Job } & - & 0.023 & - & -0.026 & - & 0.044 & - & -0.020 \\
\hline & & $(0.030)$ & & $(0.029)$ & & $(0.040)$ & & $(0.025)$ \\
\hline Observations & 1,801 & 1,801 & 1,828 & 1,828 & 1,091 & 1,091 & 2,538 & 2,538 \\
\hline
\end{tabular}


Difference

$\begin{array}{cccccccc}0.007 & 0.003 & 0.092^{* * *} & 0.048^{*} & 0.056^{* *} & 0.035 & 0.008 & -0.013 \\ (0.025) & (0.026) & (0.029) & (0.028) & (0.029) & (0.028) & (0.027) & (0.026)\end{array}$

Note: ${ }^{* * *} \mathrm{p}<0.01, * * \mathrm{p}<0.05, * \mathrm{p}<0.1$. Standard errors are in parentheses. Table shows estimated coefficients on senior year weekly work hours divided by 20 and the potential mediating factors. Whitecollar occupations and a high school degree are the excluded categories. Models include the demographic and supplemental family covariates common to both NLSY cohorts. Dollar figures are adjusted for inflation to year-2012 dollars. Wages are in logs and averaged over three survey years. 
Appendix Table A1: Descriptive Statistics: Demographic Characteristics

\begin{tabular}{|c|c|c|}
\hline & $\begin{array}{l}\frac{\text { NLSY79 (1987- }}{1989)} \\
\end{array}$ & $\begin{array}{l}\frac{\text { NLSY97 (2008- }}{2010)} \\
\end{array}$ \\
\hline \multicolumn{3}{|l|}{ Demographic Characteristics } \\
\hline \multirow[t]{2}{*}{ Male (=1 if male) } & 0.495 & 0.500 \\
\hline & $(0.008)$ & $(0.007)$ \\
\hline \multirow[t]{2}{*}{ Black (=1 if black) } & 0.140 & 0.142 \\
\hline & $(0.005)$ & $(0.005)$ \\
\hline \multirow[t]{2}{*}{ Hispanic (=1 if Hispanic) } & 0.050 & 0.119 \\
\hline & $(0.003)$ & $(0.005)$ \\
\hline \multirow[t]{2}{*}{ Age (in years) } & 26.336 & 27.098 \\
\hline & $(0.021)$ & $(0.018)$ \\
\hline \multirow[t]{2}{*}{ Marital Status (=1 if married) } & 0.508 & 0.340 \\
\hline & $(0.008)$ & $(0.007)$ \\
\hline \multirow[t]{2}{*}{ Family Size (members) } & 2.622 & 2.912 \\
\hline & $(0.023)$ & $(0.023)$ \\
\hline \multirow[t]{2}{*}{ Cigarettes (cigarettes smoked per day) } & 4.499 & 2.100 \\
\hline & $(0.143)$ & $(0.086)$ \\
\hline \multirow[t]{2}{*}{ Body Mass Index (weight divided by squared height) } & 22.286 & 24.509 \\
\hline & $(0.056)$ & $(0.083)$ \\
\hline \multirow[t]{2}{*}{ Northeast (=1 if northeast residence) } & 0.198 & 0.165 \\
\hline & $(0.006)$ & $(0.005)$ \\
\hline \multirow[t]{2}{*}{ South (=1 if south residence) } & 0.338 & 0.359 \\
\hline & $(0.007)$ & $(0.006)$ \\
\hline \multirow[t]{2}{*}{ West (=1 if west residence) } & 0.173 & 0.231 \\
\hline & $(0.006)$ & $(0.007)$ \\
\hline \multirow[t]{2}{*}{ Urbanicity (=1 if urban residence) } & 0.802 & 0.769 \\
\hline & $(0.006)$ & $(0.006)$ \\
\hline \multirow[t]{2}{*}{ Current Unemployment Rate (percent) } & 5.376 & 8.988 \\
\hline & $(0.032)$ & $(0.036)$ \\
\hline \multirow[t]{2}{*}{ Lowest Unemployment Rate (percent) } & 5.099 & 3.321 \\
\hline & $(0.028)$ & $(0.017)$ \\
\hline Sample Size & 3,637 & 3,925 \\
\hline
\end{tabular}

Weighted means are provided with standard errors are in parentheses. Adult economic outcomes are averaged over the indicated three-survey year period. 